\title{
Genetic Analysis for Diallel Crosses on Egyptian Cotton
} (Gossypium barbadense L.)

\author{
El-Aref, Kh.A.O.; I.N. Abd-El Zaher; M.H. Haridy and H.M. Shrmokh
}

Agronomy Department, Faculty of Agriculture, Al- Azhar University, Assiut Received on: $24 / 5 / 2019$

Accepted for publication on: 11/6/2019

\begin{abstract}
The present experiment was carried out to assess the general combining ability (GCA) and specific combining ability (SCA) of seven important commercial cultivars of Egyptian cotton and their $21 \mathrm{~F}_{1}$ and $\mathrm{F}_{2}$ crosses. Significant differences among genotypes were found for all studied traits. Combining ability analysis of variance revealed significant differences for GCA and SCA effects among the parents and hybrids for almost all traits. The results suggested the presence of additive and non-additive gene action for almost all of the traits. The ratio of G.C.A/S.C.A for $F_{1}$ and $F_{2}$ hybrids decreased from unity for all characters studied. The results (G.C.A) for seven parents revealed the good combiner for lint yield/plant and fiber fineness was the parent Giza 90, while for seed cotton yield/plant and seed yield /plant was the parent Giza 87 while, for fibre strength was the parent Giza 83 for $F_{1}$ and $F_{2}$ generations. In $F_{1}$ hybrid estimates of (S.C.A.) effects revealed that significant SCA effects were observed for most crosses. Moreover, the best combinations were (Giza 86 x Giza 90) for seed cotton yield /plant and fiber fineness, (Giza $88 \times$ Giza 83) for lint yield/plant and fibre strength. But the $\mathrm{F}_{2}$ hybrid of the best combinations were (Giza $90 \mathrm{x}$ Giza 83) for seed cotton yield/plant and fiber fineness, (Giza 86 x Giza 90) for lint yield/plant and fibre strength. It can be conclude that possibility of use the superior crosses for improving Egyptian cotton traits by breeding processes and selection in sequent generations.
\end{abstract}

\section{Keyword: Cotton, Gossypium barbadense, Cotton traits}

\section{Introduction}

Cotton is a warm climate crop grown in approximately 60 countries worldwide. It is cultivated from 45 North latitude to 32 South latitude by over 20 million farmers. Over 90 percent of cotton grown in the world is belong to Gossypium hirsutum L. or Upland cotton, while about ten percent of cotton in the world is related to the species G. barbadenes L, Goldringer et al. (1997). In Egypt, cotton is one of most important economic crops as it plays a vital role in our agriculture and industrial development. In recent years, the total cultivated area began to decline, which requires working to increase the production of unit area in order to compensate for the shortfall in the cultivated area. The breeders has to develop a new set of varieties with higher production, the true knowledge of gene action for various cotton treat is useful in making decisions with regard to appropriate breeding system. It is important to study the genetic diversity of Egyptian cotton varieties, which be used for the development of new cotton genotypes. Knowledge of genetic diversity and relationships among breeding materials is essential to the plant breeders for improving this crop, Mother and 
Jinks (1982). Muhammad et al. (2013) reported additive type of gene action with partial dominance for plant height, boll weight and yield of seed cotton per plant. The increase in yield per unit area of the crop is a prime concern of breeding programmers and cotton breeders all over the world. Sprague and Tatum (1942) used the term general combining ability to designate the average performance of a line in hybrid combinations, and used the term specific combining ability to define those cases in which certain combinations do relatively better or worse than the expected on the basis of the average performance of the lines involved. The present study was undertaken to study the performance, heterosis and combining ability for studied traits in seven parents and their crosses of Egyptian cotton.

\section{Materials and Methods}

This investigation was carried out during three growing seasons; 2016, 2017 and 2018. At the Experimental Farm of Faculty of Agriculture, AlAzhar University, Assiut Branch. Seven genetically diverse genotypes of Egyptian cotton wildly different in their agronomic characters were used as parental varieties in this study. These cultivars were Giza $88\left(\mathrm{P}_{1}\right)$ Giza $86\left(\mathrm{P}_{2}\right)$, Giza80 $\left(\mathrm{P}_{3}\right)$, Giza $90\left(\mathrm{P}_{4}\right)$, Giza $92\left(\mathrm{P}_{5}\right)$, Giza $87\left(\mathrm{P}_{6}\right)$ and Giza83 $\left(\mathrm{P}_{7}\right)$ were mated in a half diallel fash- ion. The description and origin of these genotypes is shown in Table (1).

In the (2016) season, the seven parental genotypes were sown in a field in two planting dates with two weeks apart to obtain enough flowers for crossing. Parents were crossed in all possible combinations except reciprocals to produce $21 \mathrm{~F}_{1}$ hybrids.

In the (2017) season, these parents were crossed again in (2016/2017) season to obtain more hybrids seeds $\left(F_{1}\right.$ 's) for all combinations. Also, the $\left(F_{1}\right.$ 's) seed were left to gave the $F_{2}$ seeds.

In (2018) season, the forty nine genotypes (seven parents and twenty - one hybrids) from each of $F_{1}$ and $F_{2}$ were sown in a Randomized Complete Block Design (R.C.B.D) with three replications. Planting was carried out on 19 March (2018). Plants were grown on rows, $4 \mathrm{~m}$ long and 60 $\mathrm{cm}$ apart, in single seeded hill spaced at $25 \mathrm{~cm}$. Each parent was represented by three rows/plot, while $F_{1}$ hybrid was represented by three row/plot and each $\mathrm{F}_{2}$ cross was represented by five rows/plot. The agriculture practices of irrigation, fertilization, used as recommended for Egyptian cotton production. The data were recorded on the mean of ten guarded plants/plot for both of parents and $F_{1}$ hybrids, and thirty guarded plants for $\mathrm{F}_{2}$ generation.

Table 1. The Pedigree and origin of the cotton varieties under investigation:

\begin{tabular}{|l|c|c|}
\hline \multicolumn{1}{|c|}{ Genotype } & Pedigree & Origin \\
\hline 1- Giza 88 & (Giza 77 x Giza45)b & Egypt \\
\hline 2- Giza 86 & Giza 75 x Giza 81 & Egypt \\
\hline 3- Giza 80 & Giza 66x Giza 73 & Egypt \\
\hline 4- Giza 90 & Giza83xDandra & Egypt \\
\hline 5- Giza 92 & Giza84 (Giza 74 x Giza 68) & Egypt \\
\hline 6- Giza 87 & Giza 89 X C.B.58 & Egypt XU.S.A \\
\hline 7- Giza 83 & Giza 67 x Giza 72 & Egypt \\
\hline
\end{tabular}




\section{The studied traits:}

1- Plant height in centimeters.

2- Boll weight in grams.

3 -Seeds cotton yield/plant in grams.

4-Seed yield/plant in grams.

5 -Lint yield/plant in grams.

6-Seed index in grams: It was determined as the weight a sample of 100 seeds in grams.

7 - fibre strength.
8- Fibre fineness.

\section{Statistical analysis:}

Statistical analysis was made on an entry mean basis. The variation among parents, $F_{1}$ and $F_{2}$ crosses was partitioned into general and specific combining abilities as illustrated by Griffing (1956) Method 2, Model I as shown in Table 2.

Table 2. Mean squares for the assumption of Method (2), Model (1) of Griffing's (1956) and expectation of mean squares.

\begin{tabular}{|l|c|c|l|}
\hline \multicolumn{1}{|c|}{ Source of variation } & D.F. & M.S. & \multicolumn{1}{c|}{ Expectation Model 1 } \\
\hline Replications & $\mathrm{b}-1$ & $\mathrm{M}_{\mathrm{b}}$ & $\sigma_{\mathrm{e}}^{2}+\mathrm{a} \theta(\mathrm{b})$ \\
\hline Genotypes & $\mathrm{a}-1$ & $\mathrm{M}_{\mathrm{v}}$ & $\sigma^{2}{ }_{\mathrm{e}}+\mathrm{b} \theta(\mathrm{v})$ \\
\hline Parents & $(\mathrm{p}-1)$ & & \\
\hline Crosses & $(\mathrm{c}-1)$ & & \\
\hline Parents v.s. crosses & 1 & & \\
\hline g.c.a. & $(\mathrm{p}-1)$ & $\mathrm{M}_{\mathrm{g}}$ & $\sigma_{e}^{2}+(\mathrm{p}+2)\left(\frac{1}{\mathrm{p}-1}\right) \sum \mathrm{g}_{\mathrm{i}}^{2}$ \\
\hline s.c.a. & $\mathrm{p}(\mathrm{p}-1) / 2$ & $\mathrm{M}_{\mathrm{s}}$ & $\sigma_{e}^{2}+\frac{2}{\mathrm{p}(\mathrm{p}-1)} \sum_{\mathrm{i}} \sum_{\mathrm{j}} \mathrm{S}_{\mathrm{ij}}^{2}$ \\
\hline Error & $(\mathrm{b}-1)(\mathrm{a}-1)$ & $\mathrm{M}_{\mathrm{e}}$ & $\sigma_{e}^{2}$ \\
\hline
\end{tabular}

\section{Heterosis estimates:}

Heterosis values was made according to (Halluer and Miranda, 1981).

A)- Heterosis from the mid-parent:

Heterosis was determined as the percentage of increase or decrease of $\mathrm{F}_{1}$ 's means over the average of its parents(M.P):

Heterosis $\%=\frac{\overline{F_{1}}-\overline{M . P}}{\overline{M . P}} \times 100$

b)-Heterosis from the better-parent:

It was also determined as the percentage of increase or decrease of $\mathrm{F}_{1}$ mean over the better parent(B.P):

Heterosis $\%=\frac{\overline{F_{1}}-\overline{B . P}}{\overline{B . P}} \times 100$

L.S.D for better parent heterosis $=\mathrm{t} \times$ $(3 \mathrm{M} . \mathrm{S} . \mathrm{E} / 2 \mathrm{r})^{1 / 2}$
L.S.D for mid parent heterosis $=\mathrm{t} \times(\mathrm{M} . \mathrm{S} . \mathrm{E} / \mathrm{r})^{1 / 2}$

Where: $t$ is the value of tabulated $t$ at a stated level of probability for the experimental error degrees of freedom; $r$ is the number of replications.

\section{Results and Discussion}

The mean of the seven parental cultivars and their 21 for $F_{1}$ and $F_{2}$ hybrids were estimated for all the studied traits and the results are presented in Table 3 and 4.

Mean performance of the studied parental cultivars varied from The results reveled that mean of parents was wide extended with a range of 94.85-120.24 $\left(\mathrm{P}_{5}-\mathrm{P}_{2}\right)$; 2.18-2.82 $\left(\mathrm{P}_{7}\right.$ $\left.\mathrm{P}_{2}\right)$; 86.06-105.23 ( $\left.\mathrm{P}_{2}-\mathrm{P}_{6}\right) ;$ 54.45$70.52\left(\mathrm{P}_{7}-\mathrm{P}_{6}\right)$; 31.60- $40.16\left(\mathrm{P}_{1}-\mathrm{P}_{3}\right)$; 
3.13 - $\left.9.16\left(\mathrm{P}_{7}-\mathrm{P}_{2}\right)\right)$; 3.05- $4.55\left(\mathrm{P}_{3}-\right.$ $\left.\mathrm{P}_{1}\right)$ and $35.7-42.8\left(\mathrm{P}_{4}-\mathrm{P}_{3}\right)$ for plant height, boll weight, seeds cotton yield/plant, seed yield/plant, lint yield/plant, seed index, fiber fineness and fiber strength respectively. Meanwhile, means of $F_{1}$ hybrids were extended with a range 86.11 -140.22 $\left(\begin{array}{lllll}\mathrm{P}_{3} & \mathrm{Xp} \\ \mathrm{P}_{4}\end{array}\right)-\left(\mathrm{P}_{4} \mathrm{Xp}_{6}\right) ; \quad 2.25 \quad-3.04 \quad\left(\mathrm{P}_{4}\right.$ $\left.\mathrm{Xp}_{5}\right)-\left(\mathrm{P}_{4} \quad \mathrm{Xp}_{7}\right) ; \quad 84.33 \quad-114.77$ $\left(\mathrm{P}_{4} \mathrm{Xp}_{5}\right)-\left(\mathrm{P}_{4} \mathrm{Xp}_{7}\right) ; 55.89-80.54\left(\mathrm{P}_{1}\right.$ $\left.\mathrm{Xp}_{7}\right)-\left(\mathrm{P}_{1} \mathrm{Xp}_{6}\right) ; 20.61-56.32\left(\mathrm{P}_{1} \mathrm{Xp}_{6}\right)-$ $\left(\mathrm{P}_{4} \mathrm{Xp}_{7}\right)$; 3.12- $9.01\left(\mathrm{P}_{2} \mathrm{Xp}_{5}\right)-\left(\mathrm{P}_{1} \mathrm{Xp}_{6}\right)$ 2.9-4.8( $\left(\mathrm{P}_{1} \mathrm{Xp}_{3}\right)-\left(\begin{array}{ll}\mathrm{P}_{1} & \mathrm{Xp}_{2}\end{array}\right)$ and 1.26$4.73\left(\mathrm{P}_{1} \mathrm{Xp}_{7}\right)-\left(\mathrm{P}_{1} \mathrm{Xp}_{2}\right)$ for the abovementioned traits, respectively. The $\mathrm{F}_{1}$ mean increased over the parental mean for all studied traits. Meanwhile, means of $F_{2}$ hybrids were extended with a range $75.65-136.76\left(\mathrm{P}_{3}\right.$ $\left.\mathrm{Xp}_{4}\right)$ - $\left(\mathrm{P}_{4} \mathrm{Xp}_{7}\right) ; 2.04-3.11\left(\mathrm{P}_{2} \mathrm{Xp}_{3}\right)$ $\left(\mathrm{P}_{4} \mathrm{Xp}_{7}\right) ; 89.98-120.75\left(\mathrm{P}_{3} \mathrm{Xp}_{7}\right)-\left(\mathrm{P}_{1}\right.$ $\left.\mathrm{Xp}_{7}\right) ; 44.33-80.78 \quad\left(\mathrm{P}_{4} \mathrm{Xp}_{5}\right)-\left(\mathrm{P}_{2}\right.$ $\left.\mathrm{Xp}_{6}\right) ; 18.17-57.18 \quad\left(\mathrm{P}_{1} \mathrm{Xp}_{6}\right)-\left(\mathrm{P}_{1}\right.$ $\left.\mathrm{Xp}_{7}\right)$; 2.22- $8.85\left(\mathrm{P}_{1} \mathrm{Xp}_{7}\right)-\left(\mathrm{P}_{1} \mathrm{Xp}_{6}\right)$; 34.00-64.25 $\left(\mathrm{P}_{1} \mathrm{Xp}_{7}\right)-\left(\mathrm{P}_{3} \mathrm{Xp}_{6}\right)$ and 22.9- $52.54\left(\mathrm{P}_{4} \mathrm{Xp}_{5}\right)-\left(\mathrm{P}_{3} \mathrm{Xp}_{5}\right)$ for plant height, boll weight, seeds cotton yield/plant, seed yield/plant, lint yield/plant, seed index, fiber fineness and fiber strength respectively.

\section{Combining ability:}

Mean squares due to both general (G.C.A) and specific (S.C.A) combining ability were highly significant for all characters studied, indicating the importance of both additive and non-additive gene effects in the inheritance of these characters. The ratio of G.C.A /S.C.A for F1 and $\mathrm{F}_{2}$ hybrids decreased from unity for all characters suggesting that nonadditive type of gene action was more important in the inheritance of these trait or appeared to be under the cen- tral of epistatic effect. Similar results were reported by Singh et al. (1987), Ali et al. (1998), Basal and Turgut (2003), Naveed et al. (2004), Rauf et al.(2005), Ashokkumar and Ravikesavan (2008), Azhar and Naeem (2008), Abro et al. (2009).

\section{A-General combining ability:}

Estimates of GCA effects (gi) for $F_{1}$ and $\mathrm{F}_{2}$ generations showed that

Giza 88 had positive and highly significant G.C.A. effects for boll weight, seeds cotton yield/plant, seed yield/plant and seed index, while it displayed a negative and highly significant G.C.A. effects for fiber fineness and fiber strength it also showed non-significant values for plant height and lint yield/plant.

Giza 86 had positive and highly significant G.C.A. effects for boll weight and fiber fineness, while it revealed a negative and highly significant G.C.A effects for seeds cotton yield/plant, seed yield/plant, lint yield/plant and fiber strength, while it non- displayed significant values for plant height and seed index.

Giza 80 had positive and highly significant G.C.A. effects for boll weight, seeds cotton yield/plant, seed yield/plant, seed index, lint yield/plant and fiber strength, while it showed a negative and highly significant G.C.A. effects for fiber fineness, while it displayed non- significant values for seed index plant.

Giza 90 had positive and highly significant G.C.A. effects for plant height, lint yield/plant and fiber strength, while it a negative displayed and highly significant G.C.A. effects for seed yield/plant and fiber fineness, while it showed non- significant values for boll weight, seeds 
cotton yield/plant, lint yield/plant and seed index.

Giza 92 had positive and highly significant G.C.A. effects for seed yield/plant, while it showed a negative and highly significant G.C.A. effects for plant height, lint yield/plant and fiber strength, while it revealed non- significant values for boll weight, seeds cotton yield/plant, seed index and fiber fineness.

Giza 78 showed positive and highly significant G.C.A. effects for plant height, seeds cotton yield/plant, seed yield/plant, seed index, while it gave a negative and highly significant G.C.A. effects for lint yield/plant and fiber strength, while it had non- significant values for boll weight and fiber fineness.

Giza 83 had positive and highly significant G.C.A. effects for plant height, while it a displayed negative and highly significant G.C.A. effects for seed yield/plant, seed index and fiber strength, while it had non- significant values for boll weight, seeds cotton yield/plant, lint yield/plant, fiber fineness.

In $\mathrm{F}_{1}$ and $\mathrm{F}_{2}$ generations showed that the $\mathrm{P}_{1}, \mathrm{P}_{2}, \mathrm{P}_{3}, \mathrm{P}_{4}, \mathrm{P}_{5}, \mathrm{P}_{6}$ and $\mathrm{P}_{7}$ were very good combiner parents for (seed yield/plant and seed index), (boll weight and fiber strength), (seeds cotton yield/plant and fiber strength), (lint yield/plant), (plant height and seed yield/plant), (seed index and fiber strength) and (plant height and seeds yield/plant) respectively. Similar results were reported by Ali et al. (1998), Basal and Turgut (2003), Naveed et al.(2004), Rauf et al. (2005), Ashokkumar and Ravikesavan (2008), Azhar and Naeem (2008), Abro et al. (2009), Karademir et al. (2009), Khan et al. (2009), Ashokkumar et al. (2010), Karademir and Gençer (2010) and Singh et al. (2010).

\section{B-Specific combining ability:}

Specific combining ability effects of the seven parents and $F_{1}$ generation are showed in Tables 6 and 7 . Concerning plant height, the crosses which had positive and highly significant S.C.A effect were $\left(\mathrm{P}_{1} \times \mathrm{P}_{5}\right)$, $\left(\mathrm{P}_{1} \times \mathrm{P}_{7}\right),\left(\mathrm{P}_{2} \times \mathrm{P}_{6}\right),\left(\mathrm{P}_{3} \times \mathrm{P}_{5}\right)$ and $\left(\mathrm{P}_{3} \times\right.$ $P_{6}$ ). While the crosses which had negative and highly significant S.C.A effect were $\left(\mathrm{P}_{1} \times \mathrm{P}_{2}\right),\left(\mathrm{P}_{2} \times \mathrm{P}_{4}\right),\left(\mathrm{P}_{3} \times\right.$ $\left.\mathrm{P}_{4}\right)$ and $\left(\mathrm{P}_{3} \times \mathrm{P}_{7}\right)$. The crosses $\left(\mathrm{P}_{3} \times\right.$ $\mathrm{P}_{5}$ ) had the highest positive effect of plant height (Table 6).

Regarding to boll weight, the crosses, which had negative and highly significant S.C.A effect were $\left(\begin{array}{llll}\mathrm{P}_{2} & \mathrm{x} & \mathrm{P}_{4}\end{array}\right)$ and $\left(\mathrm{P}_{2} \times \mathrm{P}_{7}\right)$ While the crosses which had positive and highly significant S.C.A effect were $\left(\mathrm{P}_{1} \mathrm{x}\right.$ $\left.\mathrm{P}_{4}\right),\left(\mathrm{P}_{1} \times \mathrm{P}_{7}\right),\left(\mathrm{P}_{2} \times \mathrm{P}_{3}\right),\left(\mathrm{P}_{3} \times \mathrm{P}_{6}\right)$ and $\left(\mathrm{P}_{4} \times \mathrm{P}_{7}\right)$ (Table 6).

For seed cotton yield/plant, $\left(\mathrm{P}_{1} \mathrm{x}\right.$ $\left.\mathrm{P}_{3}\right),\left(\mathrm{P}_{1} \times \mathrm{P}_{7}\right),\left(\mathrm{P}_{2} \times \mathrm{P}_{6}\right),\left(\mathrm{P}_{3} \times \mathrm{P}_{5}\right)$ and $\left(\begin{array}{llll}\mathrm{P}_{4} & \mathrm{x} & \mathrm{P}_{7}\end{array}\right)$ crosses had positive and highly significant S.C.A effect and the crosses $\left(\mathrm{P}_{1} \times \mathrm{P}_{3}\right),\left(\mathrm{P}_{5} \times \mathrm{P}_{6}\right)$ and $\left(\mathrm{P}_{5}\right.$ $\mathrm{x} \mathrm{P}_{7}$ ) were the best crosses for seed cotton yield/plant and they had the highest positive significant. Otherwise, $\left(\mathrm{P}_{4} \times \mathrm{P}_{5}\right)$ cross had negative and highly significant specific combining ability effect (Table 6).

Concerning seed yield/plant, $\left(\mathrm{P}_{5}\right.$ $\left.\mathrm{x}_{7}\right)$ and $\left(\mathrm{P}_{4} \times \mathrm{P}_{6}\right)$ crosses had positive and highly significant S.C.A effect. The $\left(\mathrm{P}_{5} \times \mathrm{P}_{7}\right)$ cross was the best for seed yield/plant and they had positive and highly S.C.A. Otherwise $\mathrm{P}_{4} \mathrm{x} \mathrm{P}_{5}$ cross had negative and highly significant S.C.A effects (Table 6). 
For lint yield/plant, $\left(\mathrm{P}_{1} \times \mathrm{P}_{3}\right),\left(\mathrm{P}_{1}\right.$ $\left.x \mathrm{P}_{4}\right),\left(\mathrm{P}_{1} \times \mathrm{P}_{7}\right),\left(\mathrm{P}_{3} \times \mathrm{P}_{6}\right),\left(\mathrm{P}_{3} \times \mathrm{P}_{5}\right),\left(\mathrm{P}_{4}\right.$ $\left.\mathrm{xP}_{7}\right)$ and $\left(\mathrm{P}_{5} \mathrm{x} \mathrm{P}_{7}\right)$ crosses had positive and highly significant and S.C.A effect. But $\left(\mathrm{P}_{1} \times \mathrm{P}_{6}\right),\left(\mathrm{P}_{3} \times \mathrm{P}_{6}\right)$ and $\left(\mathrm{P}_{4}\right.$ $\mathrm{x} \mathrm{P}_{5}$ ) crosses had negative and highly S.C.A effect (Table 7).

With regard to seed index, $\left(\mathrm{P}_{1} \mathrm{x}\right.$ $\left.\mathrm{P}_{6}\right),\left(\mathrm{P}_{2} \times \mathrm{P}_{5}\right)$ and $\left(\mathrm{P}_{3} \times \mathrm{P}_{7}\right)$ crosses had positive and highly significant S.C.A effect. The $\left(\mathrm{P}_{3} \times \mathrm{P}_{7}\right)$ cross had highest positive significant S.C.A effect. While, $\left(\mathrm{P}_{2} \times \mathrm{P}_{4}\right)$ cross had negative and highly significant S.C.A effect (Table 7).

Regrinding fiber fineness, the crosses $\mathrm{P}_{1} \times \mathrm{P}_{2}, \mathrm{P}_{1} \times \mathrm{P}_{6}, \mathrm{P}_{1} \times \mathrm{P}_{7}, \mathrm{P}_{2} \times$ $\mathrm{P}_{3}$ and $\mathrm{P}_{6} \times \mathrm{P}_{7}$ had a positive highly significant S.C.A effect. While the crosses which had the highest negative and highly significant S.C.A effect were $\mathrm{P}_{1} \times \mathrm{P}_{3}$ and $\mathrm{P}_{2} \mathrm{X}_{7}$ (Table 7).

With respect to fiber strength, $\left(\mathrm{P}_{1} \times \mathrm{P}_{3}\right),\left(\mathrm{P}_{2} \times \mathrm{P}_{5}\right),\left(\mathrm{P}_{3} \mathrm{X} \mathrm{P}_{4}\right),\left(\mathrm{P}_{3} \mathrm{x}\right.$ $\left.\mathrm{P}_{5}\right),\left(\mathrm{P}_{3} \times \mathrm{P}_{6}\right)$ and $\left(\mathrm{P}_{4} \times \mathrm{P}_{7}\right)$ crosses had a positive and highly significant specific combining ability effect. However, $\mathrm{P}_{3} \times \mathrm{P}_{6}$ was the highest positive significant specific combining ability effect. But, $\left(\mathrm{P}_{1} \times \mathrm{P}_{7}\right),\left(\mathrm{P}_{2} \times\right.$ $\left.\mathrm{P}_{3}\right),\left(\mathrm{P}_{2} \times \mathrm{P}_{4}\right),\left(\mathrm{P}_{2} \times \mathrm{P}_{7}\right)$ and $\left(\mathrm{P}_{3} \mathrm{XP}_{7}\right)$ had negative and highly significant S.C.A effect (Table 7). These results are in harmony with those obtained by Ashokkumar and Ravikesavan (2008), Azhar and Naeem (2008), Abros et al. (2009), Karademir et al. (2009), Khan et al. (2009), Ashokkumar (2010), Karademir and Gençer (2010) and Singh et al. (2010). While, specific combining ability effects of the seven parents and $\mathrm{F}_{2}$ generation are showed in Tables 6 and 7. Concerning plant height, the crosses which had positive and highly significant S.C.A effect were $\left(\mathrm{P}_{1} \times \mathrm{P}_{5}\right)$, $\left(\mathrm{P}_{1} \times \mathrm{P}_{7}\right),\left(\mathrm{P}_{2} \times \mathrm{P}_{6}\right),\left(\mathrm{P}_{3} \times \mathrm{P}_{5}\right)$ and $\mathrm{P}_{4} \times$ $\mathrm{P}_{7}$. While the crosses which had negative and highly significant S.C.A effect were $\left(\mathrm{P}_{1} \times \mathrm{P}_{2}\right),\left(\mathrm{P}_{2} \times \mathrm{P}_{7}\right),\left(\mathrm{P}_{3} \times\right.$ $\left.\mathrm{P}_{4}\right),\left(\mathrm{P}_{3} \times \mathrm{P}_{7}\right),\left(\mathrm{P}_{4} \times \mathrm{P}_{5}\right)$ and $\left(\mathrm{P}_{5} \times \mathrm{P}_{6}\right)$ the crosses $\left(\mathrm{P}_{3} \times \mathrm{P}_{5}\right)$ had the highest positive effect of plant height (Table 6).

Regarding to boll weight, the crosses, which had negative and highly significant S.C.A. effect was $\left(\begin{array}{lll}\mathrm{P}_{3} & \mathrm{x} & \mathrm{P}_{2}\end{array}\right)$. While the crosses which had positive and highly significant S.C.A. effect were $\left(\mathrm{P}_{2} \times \mathrm{P}_{6}\right),\left(\mathrm{P}_{3} \times \mathrm{P}_{6}\right)$ and $\mathrm{P}_{4} \times \mathrm{P}_{7}$ (Table 6).

For seed cotton yield/plant, $\left(\mathrm{P}_{1} \mathrm{x}\right.$ $\left.\mathrm{P}_{5}\right),\left(\mathrm{P}_{1} \times \mathrm{P}_{7}\right),\left(\mathrm{P}_{2} \times \mathrm{P}_{6}\right),\left(\mathrm{P}_{3} \times \mathrm{P}_{5}\right),\left(\mathrm{P}_{3}\right.$ $\left.\mathrm{x}_{6}\right)$ and $\left(\mathrm{P}_{4} \times \mathrm{P}_{7}\right)$ crosses had positive and highly significant S.C.A effect and the cross $\left(\mathrm{P}_{4} \times \mathrm{P}_{7}\right)$ was the best for seed cotton yield/plant revealed the highest positive significant SCA. Otherwise, $\left(\mathrm{P}_{1} \times \mathrm{P}_{6}\right),\left(\mathrm{P}_{3} \times \mathrm{P}_{4}\right)$, $\left(\mathrm{P}_{3} \times \mathrm{P}_{7}\right),\left(\mathrm{P}_{4} \times \mathrm{P}_{5}\right)$ and $\left(\mathrm{P}_{4} \times \mathrm{P}_{6}\right)$ showed the negative and highly significant SCA values (Table 6).

Concerning seed yield/plant, $\left(\mathrm{P}_{2}\right.$ $\left.\times \mathrm{P}_{6}\right),\left(\mathrm{P}_{3} \times \mathrm{P}_{5}\right)$ and $\left(\mathrm{P}_{4} \times \mathrm{P}_{6}\right)$ crosses showed positive and highly significant S.C.A. effect. The $\mathrm{P}_{3} \times \mathrm{P}_{5}$ cross was the best for seed yield/plant which revealed positive and highly S.C.A. Otherwise $\mathrm{P}_{5} \times \mathrm{P}_{4}$ cross had negative and highly significant S.C.A effects (Table 6).

For lint yield/plant $\left(\mathrm{P}_{1} \times \mathrm{P}_{4}\right),\left(\mathrm{P}_{1}\right.$ $\left.\mathrm{x} \mathrm{P}_{5}\right),\left(\mathrm{P}_{1} \times \mathrm{P}_{7}\right),\left(\mathrm{P}_{2} \times \mathrm{XP}_{4}\right),\left(\mathrm{P}_{4} \times \mathrm{PP}_{7}\right)$ and $\mathrm{P}_{5} \times \mathrm{P}_{7}$ crosses revealed positive and highly significant and S.C.A effect. While the $\left(\mathrm{P}_{1} \times \mathrm{P}_{2}\right),\left(\mathrm{P}_{1} \times \mathrm{P}_{6}\right)$ and $\left(\mathrm{P}_{6}\right.$ $\left.\mathrm{x} \mathrm{P}_{7}\right)$ crosses showed negative and highly S.C.A effect (Table 7). 
With regard to seed index, $\left(\mathrm{P}_{1} \mathrm{x}\right.$ $\left.\mathrm{P}_{6}\right),\left(\mathrm{P}_{2} \times \mathrm{P}_{5}\right)$ and $\left(\mathrm{P}_{3} \times \mathrm{P}_{7}\right)$ crosses showed positive and highly significant S.C.A effect. The $\left(\mathrm{P}_{3} \times \mathrm{P}_{7}\right)$ cross revealed highest positive significant S.C.A effect. While, $\left(\mathrm{P}_{2} \times \mathrm{P}_{4}\right)$ cross showed negative and highly significant S.C.A effect (Table 7).

Regrinding fiber fineness, the crosses $\left(\mathrm{P}_{1} \times \mathrm{P}_{4}\right),\left(\mathrm{P}_{3} \times \mathrm{P}_{4}\right)$ and $\left(\mathrm{P}_{3} \times\right.$ $\mathrm{P}_{7}$ ) showed a positive highly significant S.C.A effect. While the crosses which showed the highest negative and highly significant S.C.A effect were $\mathrm{P}_{1} \times \mathrm{P}_{5}, \mathrm{P}_{1} \times \mathrm{P}_{7}$ and $\mathrm{P}_{2} \times \mathrm{P}_{4}$ (Table 7).

With respect to fiber strength, $\left(\mathrm{P}_{1} \mathrm{XP}_{2}\right),\left(\mathrm{P}_{1} \times \mathrm{P}_{3}\right),\left(\mathrm{P}_{3} \mathrm{X} \mathrm{P}_{5}\right)$ and $\left(\mathrm{P}_{4} \mathrm{x}\right.$ $\mathrm{P}_{7}$ ) crosses showed a positive and highly significant specific combining ability effect. However, $\mathrm{P}_{3} \times \mathrm{P}_{5}$ displayed the highest positive significant SCA effect. But, $\left(\mathrm{P}_{1} \times \mathrm{P}_{5}\right),\left(\mathrm{P}_{2} \times \mathrm{P}_{4}\right)$ and $\left(\mathrm{P}_{4} \mathrm{xP}_{5}\right)$ showed negative and highly significant S.C.A effect (Table 7). These results are in harmony with those obtained by Naveed et al. (2004), Rauf et al.(2005), Ashokkumar and Ravikesavan (2008), Azhar and Naeem (2008).

\section{Heterosis:}

Data in Table 3 showed that there were significant values for the heterosis over mid and better parent for all studied traits, indicating that heterosis played an important role in the inheritance of these traits. For plant height (Giza 88 x Giza 80), (Giza 88 x Giza 90) (Giza 88 x Giza 83) and (Giza 90 x Giza 83) showed highly positive significant values for heterosis over mid parents. Highly positive significant value for heterosis over better parent were found in (Giza 88 x Giza 90) and (Giza 90 x Giza 92) for plant height $(\mathrm{cm})$. For boll weight ( Giza 90 x Giza 83) had desirable highly positive significant values for the heterosis over mid parent and better parent. (Giza 86 x Giza 87) and (Giza 90 x Giza 83) showed highly positive significant values for the heterosis over mid and better parent for seed cotton yield/plant. (Giza 86 x Giza 87) had desirable highly positive significant values for the heterosis over mid and better parent for seed yield /plant. For lint yield/plant (Giza 88 x Giza 80) had desirable highly positive significant values for the heterosis over mid and better parent. For 100 seed weight. (Giza 88 x Giza 87) and (Giza 80 x Giza 87) showed highly positive significant values for the heterosis over mid and better parent. These findings are in accordance with those of Abro et al. (2009), Karademir et al.(2009), Khan et al. (2009), Ashokkumar (2010), Karademir and Gençer (2010). 
Table 3. Mean squares of genotypes, general combining ability (GCA) and specific combining ability (SCA) and their ratios for yield and its components in cotton for $F_{1}$ and $F_{2}$ generations.

\begin{tabular}{|c|c|c|c|c|c|c|c|c|c|}
\hline S.O.V & df & $\begin{array}{l}\text { Plant } \\
\text { height }\end{array}$ & $\begin{array}{c}\text { boll } \\
\text { weight }\end{array}$ & $\begin{array}{c}\text { Seed } \\
\text { cotton } \\
\text { yield/plant }\end{array}$ & $\begin{array}{c}\text { Seed } \\
\text { yield/plant }\end{array}$ & $\underset{\text { yield/plant }}{\operatorname{lint}}$ & $\begin{array}{c}\text { seed } \\
\text { index }\end{array}$ & $\begin{array}{c}\text { Fiber } \\
\text { fineness }\end{array}$ & $\begin{array}{c}\text { fibre } \\
\text { strength }\end{array}$ \\
\hline \multicolumn{10}{|c|}{ (y) } \\
\hline Replicates & 2 & 2.48 & 0.36 & 0.719 & 1.50 & 0.34 & 0.085 & 0.052 & 0.019 \\
\hline Genotypes & 27 & $32.89 * *$ & $1.10^{* *}$ & $10.84 * *$ & $15.43 * *$ & $17.41 * *$ & $0.485 * *$ & $2.80 * *$ & $0.052 * *$ \\
\hline GCA & 6 & $50.88 * *$ & $4.7 * *$ & $32.88 * *$ & $41.66 * *$ & $68.05 * *$ & $2.08 * *$ & $7.32 * *$ & $0.178 * *$ \\
\hline SCA & 20 & $245.13^{* *}$ & $5.20 * *$ & $64.65 * *$ & $97.20 * *$ & $88.08 * *$ & $2.23 * *$ & $17.84 * *$ & $2.89 * *$ \\
\hline Error & 54 & & 0.041 & 0.87 & 2.808 & 0.24 & 0.081 & 0.24 & 0.073 \\
\hline GCA / SCA & & 0.21 & 0.90 & 0.510 & 0.429 & 0.80 & 0.929 & 0.410 & 0.616 \\
\hline \multicolumn{10}{|c|}{$\mathbf{F}_{2}$} \\
\hline Replicates & 2 & 4.08 & 0.051 & 1.875 & 2.23 & 0.55 & 0.105 & 0.082 & 0.075 \\
\hline Genotypes & 27 & $51.89 * *$ & $1.20^{* *}$ & $19.00 * *$ & $22.12 * *$ & $14.70 * *$ & $0.492 * *$ & $11.80 * *$ & $0.131 * *$ \\
\hline GCA & 6 & $160.88^{* *}$ & $2.10^{* *}$ & $22.14 * *$ & $80.40 * *$ & $62.91 * *$ & $1.88^{* *}$ & $48.98 * *$ & $0.375 * *$ \\
\hline SCA & 20 & $306.11 * *$ & $8.00 * *$ & $103.34 * *$ & $118.04 * *$ & $69.39 * *$ & $2.35^{* *}$ & $57.25 * *$ & $0.807 * *$ \\
\hline Error & 54 & 2.32 & 0.047 & 1.33 & 3.542 & 0.54 & 0.046 & 0.55 & 0.025 \\
\hline GCA / SCA & & 0.530 & 0.260 & 0.660 & 0.678 & 0.910 & 0.080 & 0.856 & 0.405 \\
\hline
\end{tabular}

Table 4. Mean performances for plant height, boll weight, seed cotton yield/plant and seed yield/plant of parents and $F_{1}$ and $F_{2}$ generations.

\begin{tabular}{|c|c|c|c|c|c|c|c|c|}
\hline \multirow[t]{2}{*}{ Traits } & \multicolumn{2}{|c|}{ Plant height } & \multicolumn{2}{|c|}{ boll weight } & \multicolumn{2}{|c|}{$\begin{array}{l}\text { Seed cotton } \\
\text { yield/plant }\end{array}$} & \multicolumn{2}{|c|}{ Seed yield/plant } \\
\hline & $\mathrm{F}_{1}$ & $\mathrm{~F}_{2}$ & $\mathrm{~F}_{1}$ & $\mathrm{~F}_{2}$ & $\mathrm{~F}_{1}$ & $\mathrm{~F}_{2}$ & $\mathrm{~F}_{1}$ & $\mathrm{~F}_{2}$ \\
\hline P1 & 101.35 & 101.35 & 2.44 & 2.44 & 97.65 & 97.65 & 66.25 & 66.25 \\
\hline P2 & 120.24 & 120.24 & 2.82 & 2.82 & 86.06 & 86.06 & 58.12 & 58.12 \\
\hline P3 & 106.44 & 106.44 & 2.42 & 2.42 & 100.11 & 100.11 & 60.25 & 60.25 \\
\hline P4 & 139.77 & 139.77 & 2.48 & 2.48 & 99.98 & 99.98 & 60.87 & 60.87 \\
\hline $\mathrm{P} 5$ & 94.85 & 94.85 & 2.33 & 2.33 & 101.12 & 101.12 & 65.77 & 65.77 \\
\hline P6 & 106.15 & 106.15 & 2.25 & 2.25 & 105.23 & 105.23 & 70.52 & 70.52 \\
\hline $\mathrm{P} 7$ & 110.34 & 110.34 & 2.18 & 2.18 & 86.56 & 86.56 & 54.45 & 54.45 \\
\hline P1XP2 & 96.66 & 90.78 & 2.53 & 2.42 & 95.66 & 0.36 & 63.38 & 63.45 \\
\hline P1XP3 & 1.12 & 109.22 & 2.35 & 2.45 & 110.05 & 1.66 & 67.88 & 69.88 \\
\hline P1XP4 & .07 & 0.12 & 2.78 & 2.2 & 105.23 & .09 & 57.54 & 57.05 \\
\hline P1XP5 & 122.92 & 125.55 & 2.31 & 2.54 & 101.12 & 116.06 & 66.76 & 68.99 \\
\hline P1XP6 & 9.55 & 113.35 & 2.27 & 2.19 & 99.75 & 96.54 & 80.54 & 79.67 \\
\hline P1XP7 & 127.66 & 125.45 & 2.66 & 2.74 & 110.33 & 120.75 & 55.98 & 64.77 \\
\hline P2XP3 & 109.11 & 100.12 & 2.91 & 2.04 & 98.54 & 94.55 & 59.98 & 59.05 \\
\hline P2XP4 & 94.57 & 122.77 & 2.41 & 2.11 & 101.44 & 101.19 & 58.78 & 52.16 \\
\hline P2XP5 & 113.42 & 99.55 & 2.38 & 2.21 & 100.09 & 96.78 & 66.54 & 60.35 \\
\hline P2XP6 & 128.45 & 133.53 & 2.64 & 2.77 & 110.25 & 111.56 & 76.78 & 80.78 \\
\hline P2XP7 & 107.47 & 97.75 & 2.29 & 2.23 & 92.27 & 90.75 & 59.67 & 53.45 \\
\hline P3XP4 & 86.11 & 75.65 & 2.76 & 2.21 & 99.85 & 90.17 & 59.65 & 55.96 \\
\hline P3XP5 & 142.12 & 135.47 & 2.35 & 2.46 & 112.33 & 113.64 & 66.55 & 76.45 \\
\hline P3XP6 & 122.25 & 116.65 & 2.83 & 2.86 & 100.01 & 111.07 & 76.89 & 77.19 \\
\hline P3XP7 & 100.04 & 88.95 & 2.33 & 2.06 & 95.55 & 89.98 & 61.88 & 54.44 \\
\hline P4XP5 & 105.83 & 95.98 & 2.25 & 2.16 & 84.33 & 92.44 & 65.99 & 44.33 \\
\hline P4XP6 & 118.34 & 122.08 & 2.37 & 2.18 & 99.65 & 90.15 & 56.98 & 53.12 \\
\hline P4XP7 & 140.22 & 136.76 & 3.04 & 3.11 & 114.77 & 114.87 & 58.98 & 63.43 \\
\hline P5XP6 & 105.22 & 93.35 & 2.42 & 2.09 & 98.65 & 96.77 & 78.46 & 63.76 \\
\hline P5XP7 & 103.25 & 89.19 & 2.28 & 2.23 & 109.67 & 97.25 & 66.74 & 59.67 \\
\hline P6XP7 & 107.24 & 102.26 & 2.39 & 2.45 & 100.11 & 109.77 & 77.85 & 78.46 \\
\hline L.S.D5\% & 3.92 & 4.71 & 0.17 & 0.28 & 2.83 & 1.33 & 0.71 & 2.36 \\
\hline L.S.D1\% & 5.24 & 6.29 & 0.23 & 0.38 & 3.79 & 1.78 & 0.95 & 3.16 \\
\hline
\end{tabular}


Website: www.aun.edu.eg/faculty_agriculture/journals_issues_form.php E-mail:ajas@aun.edu.eg

Table 5. Mean performances for lint yield/plant, seed index fiber strength and fiber fineness of parents and $F_{1}$ and $F_{2}$ generations.

\begin{tabular}{|c|c|c|c|c|c|c|c|c|}
\hline \multirow{2}{*}{ Traits } & \multicolumn{2}{|c|}{ lint yield/plant } & \multicolumn{2}{c|}{ seed index } & \multicolumn{2}{c|}{ Fiber fineness } & \multicolumn{2}{c|}{ fibre strength } \\
\cline { 2 - 9 } & $\mathrm{F}_{1}$ & $\mathrm{~F}_{2}$ & $\mathrm{~F}_{1}$ & $\mathrm{~F}_{2}$ & $\mathrm{~F}_{1}$ & $\mathrm{~F}_{2}$ & $\mathrm{~F}_{1}$ & $\mathrm{~F}_{2}$ \\
\hline P1 & 31.6 & 31.6 & 7.55 & 7.55 & 4.55 & 4.55 & 37.25 & 37.25 \\
\hline P2 & 28.24 & 28.24 & 9.16 & 9.16 & 3.5 & 3.5 & 40.05 & 40.05 \\
\hline P3 & 40.16 & 40.16 & 6.66 & 6.66 & 3.05 & 3.05 & 42.8 & 42.8 \\
\hline P4 & 39.31 & 39.31 & 6.15 & 6.15 & 3.43 & 3.43 & 35.7 & 35.7 \\
\hline P5 & 35.45 & 35.45 & 5.44 & 5.44 & 3.65 & 3.65 & 35.8 & 35.8 \\
\hline P6 & 34.81 & 34.81 & 4.46 & 4.46 & 4.05 & 4.05 & 40.2 & 40.1 \\
\hline P7 & 32.31 & 32.31 & 3.13 & 3.13 & 3.85 & 3.85 & 40.1 & 40.1 \\
\hline P1XP2 & 33.38 & 28.31 & 7.55 & 6.62 & 4.8 & 4.73 & 37.15 & 42.22 \\
\hline P1XP3 & 43.37 & 33.28 & 8.23 & 7.35 & 2.9 & 3.94 & 44.1 & 51.14 \\
\hline P1XP4 & 49.09 & 55.35 & 6.23 & 6.04 & 3.85 & 4.34 & 37.45 & 31.19 \\
\hline P1XP5 & 35.86 & 48.47 & 6.83 & 7.02 & 3.6 & 2.37 & 38.4 & 25.79 \\
\hline P1XP6 & 20.61 & 44.32 & 9.01 & 8.85 & 3.55 & 4.42 & 38.75 & 41.19 \\
\hline P1XP7 & 54.02 & 57.18 & 5.21 & 2.22 & 3.15 & 1.26 & 34 & 30.84 \\
\hline P2XP3 & 39.86 & 36.6 & 5.36 & 4.13 & 4.7 & 4.63 & 34.5 & 37.76 \\
\hline P2XP4 & 44.16 & 55.34 & 4.44 & 6.00 & 3.85 & 2.96 & 34.15 & 26.71 \\
\hline P2XP5 & 34.85 & 37.73 & 3.12 & 5.12 & 4.6 & 4.48 & 38.4 & 35.52 \\
\hline P2XP6 & 34.67 & 46.78 & 7.65 & 7.97 & 4.7 & 3.7 & 38.5 & 41.19 \\
\hline P2XP7 & 33.9 & 38.6 & 5.76 & 5.72 & 3.65 & 4.47 & 35.6 & 30.9 \\
\hline P3XP4 & 41.5 & 35.51 & 6.11 & 6.28 & 4.44 & 4.52 & 41.8 & 47.79 \\
\hline P3XP5 & 46.98 & 38.39 & 5.95 & 6.07 & 4.05 & 3.06 & 43.95 & 52.54 \\
\hline P3XP6 & 24.22 & 34.98 & 7.64 & 6.74 & 4.35 & 3.22 & 46.25 & 40.13 \\
\hline P3XP7 & 34.77 & 36.64 & 6.95 & 7.09 & 3.65 & 4.44 & 37.9 & 36.03 \\
\hline P4XP5 & 30.26 & 50.96 & 6.99 & 6.66 & 4.05 & 2.7 & 38.3 & 22.9 \\
\hline P4XP6 & 44.17 & 38.43 & 6.02 & 6.53 & 4.15 & 3.29 & 38.5 & 44.24 \\
\hline P4XP7 & 56.32 & 48.94 & 6.75 & 6.83 & 3.9 & 2.45 & 42.05 & 45.43 \\
\hline P5XP6 & 55 & 52.88 & 7.14 & 6.93 & 3.95 & 3.08 & 40.75 & 34.08 \\
\hline P5XP7 & 44.23 & 38.98 & 6.26 & 6.76 & 4.05 & 4.14 & 36.55 & 41.8 \\
\hline P6XP7 & 23.56 & 40.00 & 7.01 & 6.89 & 4.6 & 3.05 & 39.55 & 34 \\
\hline L.S.D5\% & 2.17 & 2.19 & 1.13 & 1.53 & 0.073 & 0.052 & 0.26 & 0.23 \\
\hline L.S.D1\% & 2.89 & 2.93 & 1.52 & 2.04 & 0.099 & 0.070 & 0.35 & 0.31 \\
\hline & & & & & & & & \\
\hline
\end{tabular}


Table 6. Estimates of general and specific combining ability effects for plant height, boll weight, seed cotton yield/plant and seed yield/plant in $s$ ix cotton varieties.

\begin{tabular}{|c|c|c|c|c|c|c|c|c|}
\hline \multirow[t]{2}{*}{ Traits } & \multicolumn{2}{|c|}{ Plant height } & \multicolumn{2}{|c|}{ boll weight } & \multicolumn{2}{|c|}{$\begin{array}{c}\text { Seed cotton } \\
\text { yield/plant }\end{array}$} & \multicolumn{2}{|c|}{ Seed yield/plant } \\
\hline & $\mathrm{F}_{1}$ & $\mathrm{~F}_{2}$ & $\mathrm{~F}_{1}$ & $\mathrm{~F}_{1}$ & $\mathrm{~F}_{2}$ & $\mathrm{~F}_{2}$ & $\mathrm{~F}_{2}$ & $\mathrm{~F}_{2}$ \\
\hline P1 & -0.35 & 0.2 & $-0.01 *$ & $0.04 *$ & $1.42 *$ & $3.08 *$ & $0.51 *$ & $3.32 * *$ \\
\hline $\mathrm{P} 2$ & $-1.4^{*}$ & 1.07 & $0.11^{* *}$ & $0.08 * *$ & $-3.81 * *$ & $-5.19 * *$ & $-2.07 * *$ & $-2.33 *$ \\
\hline P3 & $-2.13^{* *}$ & $-4.04 * *$ & $0.06^{* *}$ & $0.04 *$ & $1.32 *$ & $1.36^{*}$ & $0.74 *$ & $0.78^{*}$ \\
\hline $\mathrm{P} 4$ & $4.54 * *$ & $7.51 * *$ & $0.08 * *$ & -0.01 & 0.06 & -0.46 & $-4.48 * *$ & $-6.52 * *$ \\
\hline P5 & $-2.26 * *$ & $-5.17 * *$ & -0.13 & $-0.08 * *$ & 0.42 & 1.24 & $2.51 * *$ & $2.15 * *$ \\
\hline P6 & $1.17 *$ & $2.02 *$ & -0.05 & 0.01 & $2.58 * *$ & $4.48 * *$ & $7.61 * *$ & $7.51 * *$ \\
\hline P7 & $0.46^{*}$ & $1.59 *$ & $-0.06 * *$ & 0.02 & -0.98 & -0.84 & $-3.33 * *$ & $-2.59 * *$ \\
\hline L.S.D5\% & 0.45 & 1.44 & 0.01 & 0.04 & 1.02 & 1.35 & 0.49 & 0.18 \\
\hline L.S.D1\% & 2.11 & 4.02 & 0.06 & 0.08 & 3.35 & 4.36 & 2.05 & 2.55 \\
\hline P1XP2 & $-14.44 * *$ & $-19.91 * *$ & -0.05 & -0.05 & -2.53 & $-8.03^{*}$ & -0.06 & -0.84 \\
\hline P1XP3 & 0.75 & 3.64 & $-0.18^{*}$ & 0.04 & $6.73 * *$ & -1.62 & $3.11 *$ & 2.48 \\
\hline P1XP4 & 2.02 & $-7.01 *$ & $0.23 * *$ & -0.19 & $3.17 *$ & $7.97 *$ & $-3.49 *$ & -3.05 \\
\hline P1XP5 & $12.68 * *$ & $21.1 * *$ & -0.03 & 0.19 & -1.3 & $11.24 * *$ & -1.26 & 2.52 \\
\hline P1XP6 & $5.87 *$ & 1.71 & $-0.16^{*}$ & $-0.23^{*}$ & $-3.83 *$ & $-9.52 * *$ & $7.42 *$ & $5.54 *$ \\
\hline P1XP7 & $14.74 * *$ & $17.42 * *$ & $0.24 * *$ & $0.31 *$ & $9.31 * *$ & $18 * *$ & $-9.2 * *$ & 0.74 \\
\hline P2XP3 & -0.21 & $-6.33^{*}$ & $0.27 * *$ & $-0.37 * *$ & 0.45 & -0.46 & -2.21 & -2.7 \\
\hline P2XP4 & $-21.42 * *$ & 4.77 & $-0.26 * *$ & $-0.32 *$ & $4.61 *$ & $6.34 *$ & 0.33 & -2.3 \\
\hline P2XP5 & 4.23 & $-5.77 *$ & -0.07 & -0.14 & 2.9 & 0.23 & 1.1 & -0.47 \\
\hline P2XP6 & $15.83 * *$ & $21.02 * *$ & 0.1 & $0.35 * *$ & $11.9 * *$ & $13.77 * *$ & $6.24 *$ & $12.3 * *$ \\
\hline P2XP7 & -4.39 & $-11.15^{* *}$ & $-0.24 * *$ & -0.21 & $-3.52 *$ & -3.73 & 0.07 & $-4.93 * *$ \\
\hline P3XP4 & $-29.15 * *$ & $-37.23 * *$ & $0.14^{*}$ & -0.15 & -2.12 & $-9.57 * *$ & -0.13 & -1.61 \\
\hline P3XP5 & $33.66 * *$ & $35.27 * *$ & -0.06 & 0.17 & $10.01 * *$ & $12.2 * *$ & -0.22 & $12.52 * *$ \\
\hline P3XP6 & $10.36^{* *}$ & $9.26 *$ & $0.34 * *$ & $0.49 * *$ & $3.47 *$ & $8.39 * *$ & $5.02 *$ & $5.6^{*}$ \\
\hline P3XP7 & $-11.1 * *$ & $-14.84 * *$ & $-0.15^{*}$ & $-0.32 *$ & $-5.37 *$ & $-9.38 * *$ & 0.96 & $-7.05^{*}$ \\
\hline P4XP5 & $-9.3^{*}$ & $-15.77 * *$ & $-0.18^{*}$ & -0.13 & $-16.73 * *$ & $-8.84 * *$ & 2.96 & $-12.31 * *$ \\
\hline P4XP6 & -0.23 & 3.14 & $-0.14^{*}$ & -0.19 & -2.57 & $-12.37 * *$ & $11.15 * *$ & $11.17 * *$ \\
\hline P4XP7 & $22.41 * *$ & $21.42 * *$ & $0.53 * *$ & $0.73 * *$ & $15.11 * *$ & $15.67 * *$ & 1.8 & $9.24^{*}$ \\
\hline P5XP6 & -6.54 & $-12.92 * *$ & 0.12 & -0.21 & $-3.93 *$ & $-7.45^{*}$ & $3.34 *$ & $-6.9 *$ \\
\hline P5XP7 & $-5.79 *$ & $-9.31 *$ & 0.13 & $-0.23 *$ & -1.37 & -4.14 & $14.29 * *$ & 3.2 \\
\hline P6XP7 & $-7.2 *$ & $-9.31 *$ & 0.01 & $-0.24 *$ & -1.07 & -4.14 & $8.57 *$ & 3.2 \\
\hline L.S.D5\% & 4.62 & 5.63 & 0.14 & 0.23 & 3.01 & 4.63 & 3.02 & 3.53 \\
\hline L.S.D1\% & 9.85 & 11.55 & 0.22 & 0.43 & 6.52 & 8.24 & 8.75 & 10.05 \\
\hline
\end{tabular}


Website: www.aun.edu.eg/faculty_agriculture/journals_issues_form.php E-mail:ajas@aun.edu.eg

Table 7. Estimates of general and specific combining ability effects for lint yield/plant, seed index fiber strength and fiber fineness in $s$ ix cotton varieties.

\begin{tabular}{|c|c|c|c|c|c|c|c|c|}
\hline \multirow{2}{*}{ Traits } & \multicolumn{2}{|c|}{ lint yield/plant } & \multicolumn{2}{|c|}{ seed index } & \multicolumn{2}{|c|}{ Fiber fineness } & \multicolumn{2}{|c|}{ fibre strength } \\
\hline & $\mathrm{F}_{1}$ & $\mathrm{~F}_{2}$ & $\mathrm{~F}_{1}$ & $\mathrm{~F}_{1}$ & $\mathrm{~F}_{2}$ & $\mathrm{~F}_{2}$ & $\mathrm{~F}_{2}$ & $\mathrm{~F}_{2}$ \\
\hline $\mathrm{P} 1$ & 0.49 & -0.38 & $0.86^{* *}$ & $0.48 * *$ & -0.04 & $0.13 *$ & $-0.74^{*}$ & $-0.83 *$ \\
\hline $\mathrm{P} 2$ & $-1.98^{*}$ & $-2.48 *$ & -0.05 & $0.33^{*}$ & $0.22 * *$ & $0.34 * *$ & $-1.4 * *$ & $-1.1 *$ \\
\hline P3 & $1.76^{*}$ & $1.29 *$ & 0.34 & -0.01 & $-0.23 * *$ & $-0.14^{*}$ & $2.57 * *$ & $5.18 * *$ \\
\hline P4 & $5.44 * *$ & $6.64 * *$ & $-0.43^{*}$ & -0.03 & $-0.13 *$ & $-0.2 *$ & $-0.81^{*}$ & $-1.63 * *$ \\
\hline P5 & -1.19 & $1.39 *$ & $-0.36^{*}$ & $-0.18^{*}$ & 0.03 & $-0.2 *$ & $-0.36^{*}$ & $-2.23 * *$ \\
\hline P6 & $-6.32 * *$ & $-5.35 * *$ & $0.36^{*}$ & $0.29 * *$ & $0.23 * *$ & -0.01 & $1.28 * *$ & $1.19 *$ \\
\hline P7 & $1.81 *$ & $1.47 *$ & $-0.69 * *$ & $-0.79 * *$ & -0.07 & -0.16 & $-0.57^{*}$ & $-0.952^{*}$ \\
\hline L.S.D5\% & 1.75 & 0.44 & 0.35 & 0.11 & 0.10 & 0.13 & 0.35 & 0.852 \\
\hline L.S.D1\% & 3.88 & 4.33 & 0.445 & 0.28 & 0.21 & 0.33 & 0.985 & 1.28 \\
\hline P1XP2 & -2.02 & $-7.25^{* *}$ & 0.44 & -0.57 & $0.709 * *$ & $0.64 *$ & 0.41 & $6.11 * *$ \\
\hline P1XP3 & $4.23 * *$ & $-3.47 *$ & 0.73 & 0.49 & $-0.746 * *$ & 0.08 & $3.39 * *$ & $8.74 * *$ \\
\hline P1XP4 & $6.27 * *$ & $10.66^{* *}$ & -0.5 & -0.79 & 0.103 & $0.79 * *$ & 0.13 & $-4.39 *$ \\
\hline P1XP5 & -0.33 & $9.04 * *$ & 0.03 & 0.33 & -0.302 & $-1.18 * *$ & $0.60 *$ & $-9.19 * *$ \\
\hline P1XP6 & $-10.45^{* *}$ & $-14.52 * *$ & $2.82 * *$ & $1.89 * *$ & $0.552 * *$ & $0.68 *$ & $-0.67 *$ & 2.79 \\
\hline P1XP7 & $14.83^{* *}$ & $17.67 * *$ & $-1.26^{*}$ & $-1.64 *$ & $0.652 * *$ & $-2.33 * *$ & $-3.57 * *$ & $-5.80 * *$ \\
\hline P2XP3 & $3.19 *$ & 1.95 & $-1.23 *$ & $-2.97 * *$ & $0.793 * *$ & $0.57 *$ & $-5.54 * *$ & $-4.36 *$ \\
\hline P2XP4 & $3.81 *$ & $12.76^{* *}$ & $-3.6 * *$ & -0.56 & -0.159 & $-0.79 * *$ & $-2.51 * *$ & $-8.60 * *$ \\
\hline P2XP5 & 1.13 & 0.4 & $2.77 * *$ & $3.41 * *$ & $0.437 *$ & $0.73 * *$ & $1.26 * *$ & 0.82 \\
\hline P2XP6 & $6.08^{* *}$ & 1.39 & $1.07^{*}$ & 1.07 & 0.337 & -0.24 & -0.26 & 3.06 \\
\hline P2XP7 & $-2.82 *$ & 1.19 & 0.2 & -0.2 & $-0.613 * *$ & $0.68 *$ & $-1.31 * *$ & $-5.47 *$ \\
\hline P3XP4 & $-2.6^{*}$ & $-8.26 * *$ & -0.21 & -0.06 & -0.014 & $0.99 * *$ & $1.17 * *$ & $6.20 * *$ \\
\hline P3XP5 & $9.51 * *$ & -0.12 & -0.33 & -0.12 & $0.331 *$ & $-0.46^{*}$ & $2.84 * *$ & $11.55 * *$ \\
\hline P3XP6 & $-8.11 * *$ & $3.2 *$ & 0.67 & 0.17 & $0.431 *$ & $-0.50 *$ & $3.53 * *$ & $-4.28 *$ \\
\hline P3XP7 & $-5.69 * *$ & -1.96 & $3.11 * *$ & $3.5^{* *}$ & 0.031 & $0.88 * *$ & $-2.97 * *$ & $-6.63 * *$ \\
\hline P4XP5 & $-10.89 * *$ & $4.51 *$ & $1.48^{*}$ & 0.49 & 0.23 & $-0.51 *$ & $0.58 *$ & $-11.28 * *$ \\
\hline P4XP6 & $8.16^{* *}$ & -1.28 & -0.18 & -0.02 & 0.13 & -0.12 & $-0.84^{*}$ & $6.64 * *$ \\
\hline P4XP7 & $12.18 * *$ & $6.41 * *$ & $1.57^{*}$ & $1.27^{*}$ & 0.18 & $-0.81 * *$ & $4.56 * *$ & $9.59 * *$ \\
\hline P5XP6 & $-7.99 * *$ & -0.05 & 0.87 & 0.53 & -0.224 & -0.33 & $0.93 *$ & $-2.92 *$ \\
\hline P5XP7 & $16.12 * *$ & $6.87 * *$ & $1.89 *$ & $1.51 *$ & 0.076 & -0.17 & 2.78 & -1.16 \\
\hline P6XP7 & $-8.82 * *$ & $-6.87 * *$ & $1.07 *$ & $1.52 *$ & $0.526 * *$ & -0.176 & -0.03 & -1.16 \\
\hline L.S.D5\% & 2.16 & 2.83 & 1.06 & 1.13 & 0.33 & 0.34 & 0.55 & 2.32 \\
\hline L.S.D1\% & 4.22 & 5.43 & 2.62 & 2.84 & 0.545 & 0.707 & 2.54 & 5.75 \\
\hline
\end{tabular}


Table 8. Heterosis as percentage of mid-parents (M.P) and better Parent (B.P) in the $F_{1}$ crosses for plant height, boll weight, seed cotton yield/plant and seed yield/plant.

\begin{tabular}{|c|c|c|c|c|c|c|c|c|}
\hline \multirow[t]{2}{*}{ Traits } & \multicolumn{2}{|c|}{ Plant height } & \multicolumn{2}{|c|}{ boll weight } & \multicolumn{2}{|c|}{$\begin{array}{l}\text { Seed cotton } \\
\text { yield/plant }\end{array}$} & \multicolumn{2}{|c|}{ Seed yield/plant } \\
\hline & M.P & B.P & M.P & B.P & M.P & B.P & M.P & B.P \\
\hline P1XP2 & $-12.76^{* *}$ & $-7.86^{*}$ & $-3.8 * *$ & $6.74 * *$ & $4.14 *$ & $5.93 *$ & 1.92 & $-6.14 *$ \\
\hline P1XP3 & $6.95 * *$ & -2.39 & $-3.29 *$ & -0.41 & $11.3^{* *}$ & -1.23 & $7.32 *$ & -4.53 \\
\hline P1XP4 & -1.24 & $13.74 * *$ & $13.01 * *$ & -0.81 & $6.49 *$ & -1.17 & $-9.47 *$ & -4.06 \\
\hline P1XP5 & $25.3 * *$ & -3.21 & $-3.14 *$ & -2.25 & 1.75 & -1.72 & 1.14 & -0.36 \\
\hline P1XP6 & $15.23 * *$ & -2.26 & $-3.2 *$ & -3.89 & -1.67 & -3.6 & $17.77 * *$ & -3.03 \\
\hline P1XP7 & $20.61 * *$ & -4.07 & $15.15^{* *}$ & $-5.33^{*}$ & $19.79 * *$ & $-5.68 *$ & $-7.24 *$ & $-8.91 *$ \\
\hline P2XP3 & -3.73 & $-5.74 *$ & $11.07 * *$ & $-7.09 * *$ & $5.86^{*}$ & $-7.02 *$ & 1.34 & -1.77 \\
\hline P2XP4 & $-27.26^{* *}$ & $-6.99 *$ & $-9.06^{* *}$ & $-6.03 * *$ & $9.05 * *$ & $8.96^{* *}$ & -1.2 & -1.25 \\
\hline P2XP5 & $5.46^{*}$ & $-10.56^{*}$ & $-7.57^{* *}$ & $-8.69 * *$ & $6.95 * *$ & $-7.45^{* *}$ & $7.42 *$ & 2.81 \\
\hline P2XP6 & $13.48^{* *}$ & $-5.86^{*}$ & $4.14 * *$ & $10.11 * *$ & $15.27 * *$ & $9.11 * *$ & $19.37 * *$ & $11.79 * *$ \\
\hline P2XP7 & $-6.78^{*}$ & -4.12 & $8.4^{* *}$ & $11.35 * *$ & $6.91 * *$ & -0.29 & $6.01 *$ & -3.16 \\
\hline P3XP4 & $-30.05 * *$ & $-11.92 * *$ & $12.65^{* *}$ & -1.21 & $\begin{array}{l}-0.19 \\
\end{array}$ & -0.06 & -1.5 & -0.51 \\
\hline P3XP5 & $41.21 * *$ & $-5.44^{*}$ & -1.05 & -1.86 & $11.64 * *$ & -0.5 & $5.62 *$ & -4.2 \\
\hline P3XP6 & $15.01 * *$ & -0.14 & $21.2 * *$ & -3.51 & -2.59 & -2.43 & $17.6^{* *}$ & $-7.28 *$ \\
\hline P3XP7 & $-7.7^{*}$ & -1.77 & 1.3 & $-4.96 *$ & 2.37 & $-6.77^{*}$ & $7.9^{*}$ & -4.81 \\
\hline P4XP5 & $-9.79 * *$ & $16.07 * *$ & $-6.44 * *$ & -3.02 & $-16.13 * *$ & -0.56 & 4.22 & -3.73 \\
\hline P4XP6 & -3.76 & $-12.03 * *$ & 0.21 & $-4.64 *$ & -2.88 & -2.49 & $-13.27 * *$ & $-6.84 *$ \\
\hline P4XP7 & $12.13^{* *}$ & $-10.53^{*}$ & $30.47 * *$ & $6.05 * *$ & $23.05 * *$ & $8.71^{* *}$ & 2.29 & -5.27 \\
\hline P5XP6 & $4.7^{*}$ & $-5.32 *$ & $5.68 * *$ & -1.72 & $-4.39 *$ & -1.95 & $15.14^{* *}$ & -3.37 \\
\hline P5XP7 & 0.64 & $-5.97 *$ & 1.11 & -3.22 & $16.87^{* *}$ & -7.2 & $11.03^{* *}$ & $-8.61 *$ \\
\hline P6XP7 & -0.93 & -1.9 & $7.9^{* *}$ & -1.56 & $4.4^{*}$ & $-8.87 * *$ & $24.59 * *$ & $11.39 * *$ \\
\hline L.S.D5\% & 4.55 & 5.22 & 2.26 & 4.35 & 3.67 & 4.75 & 5.35 & 6.09 \\
\hline L.S.D1\% & 10.13 & 11.44 & 3.53 & 5.65 & 6.66 & 7.15 & 10.55 & 11.37 \\
\hline
\end{tabular}


Website: www.aun.edu.eg/faculty_agriculture/journals_issues_form.php E-mail:ajas@aun.edu.eg

Table 9. Heterosis as percentage of mid-parents (M.P) and better Parent (B.P) lint yield/plant, seed index fiber strength and fiber fineness in the $F_{1}$ crosses.

\begin{tabular}{|c|c|c|c|c|c|c|c|c|}
\hline \multirow{2}{*}{ Traits } & \multicolumn{2}{|c|}{ lint yield/plant } & \multicolumn{2}{|c|}{ seed index } & \multicolumn{2}{|c|}{ Fiber fineness } & \multicolumn{2}{|c|}{ fibre strength } \\
\hline & M.P & B.P & M.P & B.P & M.P & B.P & M.P & B.P \\
\hline P1XP2 & $11.56^{* *}$ & -5.32 & $-9.63 *$ & -8.79 & 19.25 & 5.49 & -3.88 & $-7.24 *$ \\
\hline P1XP3 & $0.88 * *$ & $10.66^{* *}$ & $15.83^{* *}$ & -5.89 & -23.68 & $-36.26 * *$ & $10.18^{* *}$ & 3.04 \\
\hline P1XP4 & $38.46^{* *}$ & $-9.81 *$ & $-9.05^{*}$ & $-9.27 *$ & -3.51 & $15.38^{* *}$ & 2.67 & 0.54 \\
\hline P1XP5 & 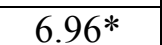 & -5.43 & 5.16 & $13.97 * *$ & -12.2 & $*$ & $5.13 *$ & 3.09 \\
\hline P1XP6 & $37.93 * *$ & -4.61 & $50.04 * *$ & $20.46 * *$ & -17.44 & $-21.98 * *$ & -0.24 & -4.18 \\
\hline P1XP7 & 9.0 & -1.1 & -2.43 & $29.27^{* *}$ & -25 & $-30.77 * *$ & $-12.09 * *$ & $-15.21 * *$ \\
\hline P2XP3 & 16.55 & $14.84 * *$ & $-32.24 * *$ & $13.65 * *$ & 43.51 & $34.29 * *$ & $-16.72 * *$ & $-19.39 * *$ \\
\hline P2XP4 & $30.75 * *$ & $14.08 * *$ & $-42 * *$ & $-16.43 * *$ & 11.11 & 10 & $-9.83 *$ & $-14.73 * *$ \\
\hline P2XP5 & $9.44 * *$ & $-10.17 *$ & $-57.26 * *$ & $-20.31 * *$ & 28.67 & $26.03 * *$ & 1.25 & -4.12 \\
\hline P2XP6 & $9.98 * *$ & $-9.44 *$ & $12.33^{* *}$ & $25.66^{* *}$ & 24.5 & $16.05 * *$ & -4.34 & -4.8 \\
\hline P2XP7 & $11.97 * *$ & -6.3 & -6.27 & $-32.91 * *$ & -0.68 & -5.19 & $11.17 * *$ & $11.22 * *$ \\
\hline P3XP4 & 4.44 & 1.08 & -4.61 & -3.83 & 9.57 & 3.5 & $6.5^{*}$ & -2.34 \\
\hline $\mathrm{P} 3 \mathrm{X}$ & 4.27 & 6 & -1.65 & $-9.16^{*}$ & 20.9 & $10.96^{*}$ & $11.83^{* *}$ & 2.69 \\
\hline P3XP6 & $-35.39 * *$ & -6.66 & $37.41 * *$ & $16.52 * *$ & 22.54 & 7.41 & $11.12 * *$ & $8.06^{*}$ \\
\hline P3XP7 & -4.04 & $-9.77 *$ & $41.98 * *$ & $-26.5^{* *}$ & 5.8 & -5.19 & $-8.56^{*}$ & $-11.45 * *$ \\
\hline P4XP5 & $19.05 * *$ & -4.91 & $20.62 * *$ & -5.77 & 14.41 & $10.96^{* *}$ & $7.13^{*}$ & $6.98^{*}$ \\
\hline P4XP6 & $19.19 * *$ & -5.72 & $13.48 * *$ & $-13.74 * *$ & 10.96 & 2.47 & 1.13 & -4.8 \\
\hline P4XP7 & $57.27 * *$ & $-8.9^{*}$ & $45.47 * *$ & $24.55^{* *}$ & 7.14 & 1.3 & 10.95 & 4.86 \\
\hline P5XP6 & $-39.11 * *$ & $\begin{array}{l}-0.9 \\
\end{array}$ & $44.24 * *$ & $-9.01 *$ & 2.6 & 8.22 & 6.9 & 0.77 \\
\hline P5XP7 & $30.55 * *$ & -4.43 & $46.09 * *$ & $-21.23 * *$ & 8* & 5.19 & -3.69 & $-8.85 *$ \\
\hline P6XP7 & $-29.8 * *$ & -3.59 & $84.72 * *$ & $-14.91 * *$ & 16.46 & $13.58 * *$ & -1.79 & -2.2 \\
\hline & 5. & & 7.67 & 8.97 & 7.67 & 8.97 & 5.12 & 7.25 \\
\hline L.S.D1\% & 7.58 & 10.65 & 9.96 & 12.05 & 9.96 & 12.05 & 10.23 & 11.12 \\
\hline
\end{tabular}

\section{References}

Abro, S., Kandhro M. M., Laghari S., Arain M. A. and Deho Z.A. (2009). Combining Ability and Heterosis for Yield Contributing Traits in Upland Cotton (Gossypium hirsutum L.). Pak. J. Bot., 41(4): 1769-1774.

Ali, B., Khan I.A. and Aziz K. (1998). Study Pertaining to the Estimation of Variability, Heritability and Genetic Advance in Upland Cotton. Pak. J. Biol. Sci., 1(4): 307-308.

Ashokkumar, K. and Ravikesavan R., (2008). Genetic Studies of Combining Ability Estimates for Seed Oil, Seed Protein and Fibre Quality Traits in Upland Cotton (G. hirsutum L.). Res. Agric. Biol. Sci., 4(6): 798-802.

Ashokkumar, K., Ravikesavan, R and Jebakumar Prince, K.S. (2010).
Combining Ability Estimates for Yield and Fibre Quality Traits In Line $\times$ Tester Crosses of Upland Cotton, (Gossypium hirsutum). Int.J. Biol., 2(1): 179-190.

Azhar, F.M. and Naeem M., (2008). Assessment of Cotton (Gossypium Hirsutum) Germplasm for Combining Abilities in Fiber Traits. J. Agric. Soc. Sci., 4(3): 120-131.

Basal, H. and Turgut I. (2003). Heterosis and Combining Ability for Yield Components and Fiber Quality Parameters in a Half Diallel Cotton (G. hirsutum L.) Population. Turk. J. Agric. For., 27(4): 207212.

Golderinger, I., P. Prabant and A. Gallais, (1997). Estimates of additive and epistatic genetic variances for agronomic traits in apopulation of doubled- haploid lines of wheat. Heredity, 79:60-71. 
Griffing, B. (1956). Concept of General and Specific Combining Ability in Relation to Diallel Crossing Systems. Aust. J. Bio. Sci., 9: 463493.

Halluer, A.R. and J.B. Miranda (1981). Quantitative genetics in maize breeding. Iowa State Univ. Press, Ames. USA

Karademir, E. and Gençer, O. (2010). Combining Ability and Heterosis for Yield and Fiber Quality Properties in Cotton (G. Hirsutum L.) Obtained by Half Diallel Mating Design. Not. Bot. Horti Agrobo. Cluj-Napoca, 38(1): 222-227.

Karademir C., Karademir E., Ekinci R., and Gençer O. (2009). Combining Ability Estimates and Heterosis for Yield and Fiber Quality of Cotton in Line $\times$ Tester Design. Not. Bot. Horti Agrobo. Cluj-Napoca, 37(2): 228-233.

Khan N. U., Hassan G., Kumbhar M. B., Marwat K. B., Khan M. A., Parveen A., Umm-e-Aiman, and Saeed, M. (2009). Combining Ability Analysisto Identify Suitable Parents for Heterosis in Seed Cotton Yield, its Components and Lint $\%$ in Upland Cotton. Ind. Crops Prod. 29: 108-115.

Mather, K. and J.L. Jinks, (1982). Biometrical Genetics. 3ed Chapman and Hall, London n. pp: 396 of some economic traits in cotton. M.Sc. Thesis, Fac. of Agric., A1Azher Univ., Cairo, Egyptian.
Muhammad, M.R., Muneeb, M., Ghazanfar, H., Rasheda, A., Sajida, H., Amir, L., (2013). Genetic analysis of some metric plant traits in upland cotton (Gossypium hirsutum L.) through hybridization. Universal J. of Plant Sci. 1(1): 1-7, 2013.

Naveed, M., Azhar, F. M. and Ali, A. (2004). Estimates of Heritabilities and Correlations among Seed Cotton Yield and Its Components in Gossypium hirsutum L.. Int. J. Agri. Biol., 6(4): 712-714.

Rauf, S., Khan, T.M. and Nazir, S. (2005). Combining Ability and Heterosis in Gossypium hirsutum L.. Int. J. Agri. Biol., 7(1): 109113.

Singh, M., Singh, T. H. and Randhawa, L. S. (1987). Combining Ability Analysis for Fiber Quality Characters in Upland Cotton. Cotton Improvement, 14(2): 136-140.

Singh, S., Singh, V. V., and Choudhary, A.D. (2010). Combining Ability Estimates for Oil Content, Yield Components and Fibre Quality Traits in Cotton (G. hirsutum) Using an $8 \times 8$ Diallel Mating Design. Tropical Subtropical Agroecosystems, 12: 161- 166.

Sparague, G.F. and L.A. Tatum (1942). General vs specific combining ability in single crosses of corn. J. American Soc. Agron., 34:923925. 
التحليل الوراثي للهجن الدائرية في القطن المصري

خلف عبد المجيد عمر العارف، ابراهيم نجاح عبد الظاهر، مختار حسن هريدي وحمادة مصطفى شرموخ

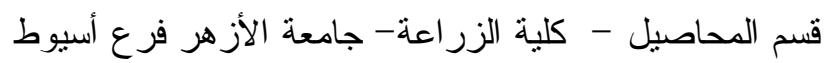

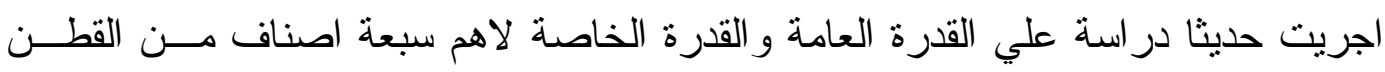

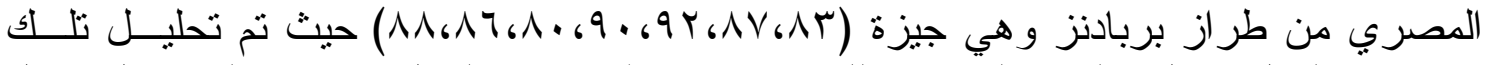

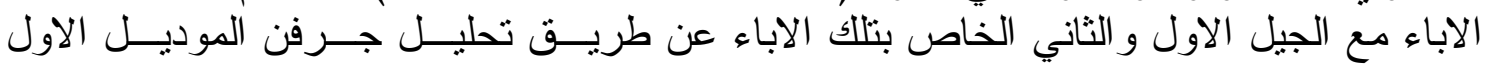

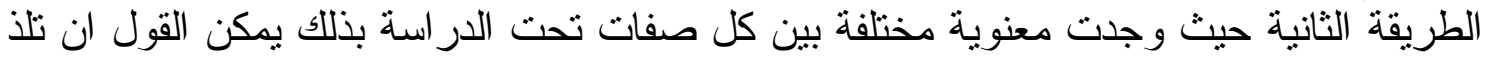

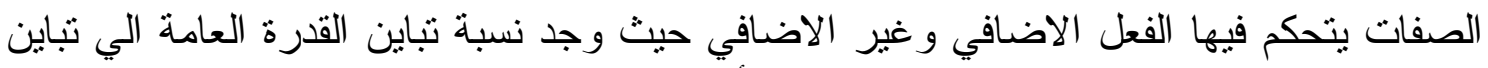

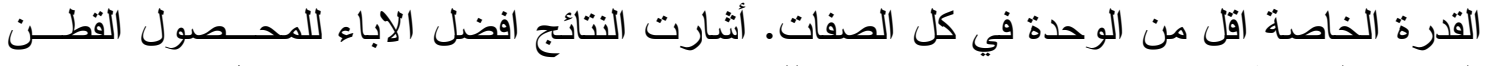

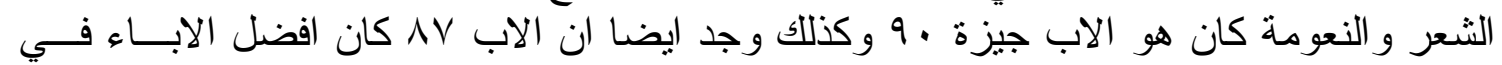

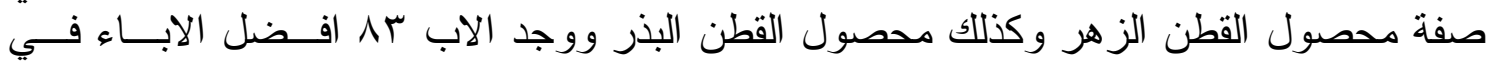

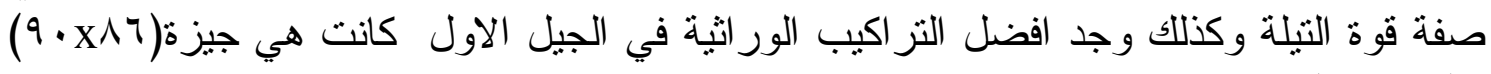

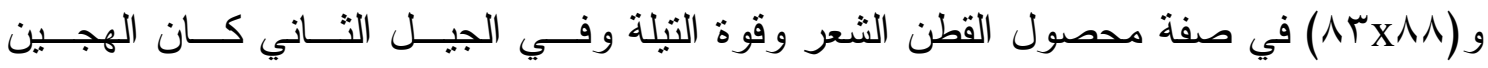

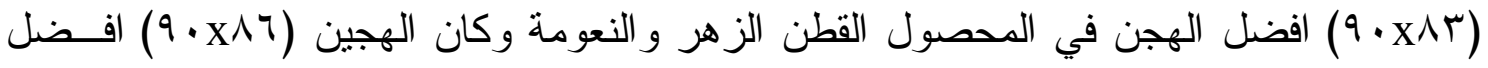
الهحن في المحصول الثطعر و النعومة و المتانة. 